\title{
Knowledge and Attitudes Regarding Covid-19 Prevention in the Music Community
}

\author{
Pengetahuan dan Sikap Mengenai Pencegahan Covid-19 pada Komunitas Musik
}

\section{Lia H. Andayani. ${ }^{1}$ Ferry Sandra, ${ }^{2}$ Abdul G. Soulissa, ${ }^{1}$ James Handojo ${ }^{3}$}

\author{
${ }^{1}$ Department of Preventive and Public Health Dentistry, Faculty of Dentistry, Trisakti \\ University, Jakarta, Indonesia \\ ${ }^{2}$ Department of Oral Biology Faculty of Dentistry, Trisakti University, Jakarta, Indonesia \\ ${ }^{3}$ Department of Prosthodontics, Faculty of Dentistry, Trisakti University, Jakarta, Indonesia \\ Email: lia@trisakti.ac.id \\ Received: August 25, 2021; Accepted January 14, 2022; Published on line; January 17, 2022
}

\begin{abstract}
The escalation of COVID-19 cases both in morbidity and mortality rates in Daerah Khusus Ibukota (DKI) Jakarta and its surrounding areas (JABODETABEK) continues to occur. Adherence in implementing health protocols depends on the knowledge and attitudes of the individuals. This study aimed to assess the knowledge and attitude regarding Covid-19 prevention in an informal community, namely music community. This study was conducted online with 44 participants obtained through convenience sampling method. Participants filled out the questionnaires covering individual characteristics, general knowledge regarding Covid-19, and attitudes towards protective measures against Covid-19. The Mann-Whitney test was used to analyze the differences in the mean score of knowledge based on selected variables. There were $52.4 \%$ of participants that had low level of knowledge. Meanwhile, $86.4 \%$ of participants had positive attitude towards protective measures against Covid-19. Significant differences were found in the mean scores of knowledge based on age $(\mathrm{p}=0.001)$, place of residence $(\mathrm{p}=0.004)$, and occupational status ( $\mathrm{p}=0.032$ ). In conclusion, most participants of the music community in Jakarta and surrounding areas have low level of knowledge, however, they have positive attitude towards protective measures against Covid-19.
\end{abstract}

Keywords: Covid-19; knowledge; attitude; music community

\begin{abstract}
Abstrak: Peningkatan kasus Covid-19 baik dalam angka morbiditas maupun mortalitas di wilayah Daerah Khusus Ibukota (DKI) Jakarta dan sekitarnya (JABODETABEK) masih berlangsung. Kepatuhan dalam menerapkan protokol kesehatan bergantung pada pengetahuan dan sikap individu. Penelitian ini bertujuan untuk mengetahui gambaran pengetahuan dan sikap mengenai pencegahan Covid-19 pada salah satu komunitas informal di masyarakat, yaitu komunitas musik. Penelitian ini dilakukan secara daring dengan 44 peserta yang didapatkan melalui metode convenience sampling. Peserta mengisi kuesioner survei yang berisi data karateristik individu, pengetahuan umum, dan sikap terkait Covid-19. Uji Mann-Whitney digunakan untuk melihat perbedaan rerata nilai pengetahuan berdasarkan setiap variabel. Hasil penelitian mendapatkan sebanyak 52,4\% responden memiliki tingkat pengetahuan rendah namun $86,4 \%$ responden memiliki sikap positif terhadap upaya pencegahan penularan Covid-19. Perbedaan rerata nilai pengetahuan secara bermakna ditemukan berdasarkan usia $(\mathrm{p}=0,001)$, wilayah tinggal $(\mathrm{p}=0,004)$, dan status pekerjaan $(\mathrm{p}=0,032)$. Simpulan penelitian ini ialah sebagian besar komunitas musik di DKI Jakarta dan sekitarnya memiliki tingkat pengetahuan rendah namun memiliki sikap positif terhadap upaya pencegahan penularan Covid -19 .
\end{abstract}

Kata kunci: Covid-19; pengetahuan; sikap; komunitas musik 


\section{PENDAHULUAN}

Coronavirus disease-19 (Covid-19) disebabkan oleh severe acute respiratory syndrome coronavirus-2 (SARS-CoV-2), yang dapat ditularkan melalui droplet dan aerosol. ${ }^{1}$ Sejak dinyatakan sebagai pandemi oleh World Health Organization (WHO) pada awal 2020, jumlah kasus positif Covid-19 di Indonesia terus bertambah. Indonesia bahkan memiliki angka case fatality rate (CFR) tertinggi di kawasan Asia Tenggara, yaitu sebesar 2,8\%. Sebanyak $25 \%$ dari jumlah kasus positif Covid-19 dan $17 \%$ dari jumlah kematian akibat Covid-19 di Indonesia tercatat di Jakarta. $^{2}$

Manifestasi klinis penderita Covid-19 bervariasi dari mulai tanpa gejala (asimtomatik), gejala ringan, pneumonia, acute respiratory distress syndrome (ARDS), hingga syok sepsis. ${ }^{1}$ Gejala yang cukup sering ditemukan ialah demam, batuk kering, kelelahan, nyeri otot, sesak napas, dan diare. ${ }^{3,4}$ Tingkat penularan SARS-CoV-2 jauh lebih tinggi dibandingkan SARS-CoV dan MERSCoV. Selama masa inkubasi 2-14 hari, SARS-CoV-2 dapat ditularkan oleh individu yang tidak memiliki gejala penyakit. ${ }^{4}$

Penyebaran Covid-19 memiliki dampak psikologis dan sosial yang luas di masyarakat, selain peningkatan angka morbiditas dan mortalitas. Sebuah penelitian di Indonesia melaporkan adanya dampak psikologis berupa depresi ringan dan kecemasan ringan akibat pandemi. Manifestasi dapat berupa perubahan pola tidur dan makan, penurunan tingkat konsentrasi, kondisi penyakit kronis yang semakin memburuk, dan peningkatan konsumsi alkohol atau rokok. ${ }^{5}$

Langkah-langkah preventif untuk mengatasi Covid-19 masih menjadi pilihan utama karena belum ditemukannya terapi pengobatan yang tepat. Salah satu langkah preventif ialah kebijakan pembatasan sosial oleh pemerintah. Pembatasan sosial untuk menekan angka penularan suatu penyakit dilakukan berdasarkan pada pertimbangan epidemiologi penyakit tersebut, serta besarnya ancaman yang dapat timbul. ${ }^{6}$ Selain pembatasan sosial, upaya pencegahan Covid-19 juga bergantung pada kepatuhan masyarakat terhadap penerapan protokol kesehatan.
Kepatuhan untuk menerapkan protokol kesehatan dapat dipengaruhi oleh pengetahuan dan sikap individu terhadap pandemi ini. ${ }^{7,8}$

Pengetahuan dan sikap terhadap penyakit menular dapat dikaitkan dengan tingkat kepanikan masyarakat yang berpotensi mempersulit upaya pencegahan penyakit. ${ }^{8}$ Pengetahuan tentang Covid-19 yang diperlukan meliputi konsep dasar penyakit, cara penularan, serta pencegahan penularan. ${ }^{9}$ Upaya pencegahan dasar seperti menjaga kebersihan tangan, menggunakan masker, menjaga jarak dengan individu lain, tidak menyentuh bagian wajah seperti mata, hidung ataupun mulut, serta mencari pertolongan medis jika mengalami gejala, ialah hal-hal yang perlu diketahui dengan baik oleh masyarakat. ${ }^{10}$

Komunitas musik Indonesian Bloodbrothers terdiri dari para pelaku musik aktif dan penikmat musik secara pasif. Para pelaku musik aktif sangat bergantung pada sektor musik dan hiburan sebagai mata pencaharian. Kelompok penikmat musik pasif umumnya memiliki kebiasaan berkumpul untuk menikmati musik bersama-sama. Ketika komunitas ini berkumpul baik untuk bermain musik ataupun menikmati musik, terdapat risiko ketidakpatuhan terhadap protokol kesehatan, seperti tidak melakukan physical distancing, tidak menggunakan masker, dan tidak langsung membersihkan diri setelah selesai berkumpul. Berdasarkan latar belakang yng dipaparkan maka penulis tertarik untuk mengetahui gambaran pengetahuan dan sikap komunitas musik Indonesian Bloodbrothers terhadap pencegahan Covid-19 di wilayah Jakarta dan sekitarnya yaitu Bogor, Depok, Tangerang, dan Bekasi (JABODETABEK).

\section{METODE PENELITIAN}

Penelitian ini dilaksanakan pada bulan Desember 2020 di Jakarta dengan menggunakan metode observasional deskriptif Pengambilan data dilakukan dengan metode convenience sampling pada kegiatan penyuluhan mengenai pencegahan penularan Covid-19 yang dilakukan secara dalam jaringan (daring). Responden diambil dari anggota komunitas musik Indonesian Bloodbrothers di wilayah JABODETABEK. 
Sebanyak 44 responden menyetujui informed consent dan mengisi kuesioner berisi data pribadi, 20 item pertanyaan pengetahuan, serta 10 item pernyataan sikap mengenai pencegahan Covid-19. Data pribadi berisi karateristik responden seperti usia, jenis kelamin, wilayah tempat tinggal, status pendidikan terakhir, status pekerjaan dan status pendapatan setiap bulan.

Kuesioner untuk mengukur pengetahuan disusun berdasarkan pedoman pencegahan dan pengendalian Covid-19 oleh Kementerian Kesehatan Republik Indonesia (Kemenkes RI). ${ }^{6}$ Materi pengetahuan yang hendak diukur mencakup etiologi, gejala klinis, metode penularan, serta metode pencegahan Covid-19. Pengetahuan responden dinyatakan baik jika dapat menjawab lebih dari $80 \%$ pertanyaan dengan benar. ${ }^{11}$

Kuesioner untuk mengukur sikap responden dibuat berdasarkan instrumen yang telah digunakan dalam penelitian sebelumnya. ${ }^{7,12-14}$ Kuesioner sikap berisi 10 pernyataan dengan pilihan tiga tingkatan jawaban yaitu: setuju (3), ragu-ragu (2), dan tidak setuju (1). Sikap positif dinyatakan apabila nilai skor sama dengan atau lebih besar dari $80 \%$ nilai total skor tertinggi $(>24) .{ }^{13}$ Perbedaan tingkat pengetahuan responden berdasarkan karateristik individu dianalisis menggunakan uji Mann-Whitney. Penelitian ini telah mendapatkan persetujuan etik dari Komisi Etik Penelitian Kesehatan (KEPK) Fakultas Kedokteran Gigi (FKG) Universitas Trisakti (Usakti) dengan nomor 433/ S3/KEPK/FKG/12/2020.

\section{HASIL PENELITIAN}

Tabel 1 memperihatkan karateristik responden penelitian. Responden laki-laki berjumlah lebih banyak $(56,8 \%)$ dibandingkan responden perempuan (43,2\%). Mayoritas responden berusia di atas 30 tahun $(65,9 \%)$, berdomisili di wilayah Jakarta $(54,6 \%)$, memiliki latar belakang pendidikan SMU atau setara $(77,3 \%)$, dan memiliki pendapatan tetap setiap bulan $(56,8 \%)$. Pengetahuan responden mengenai pencegahan Covid-19 masih kurang baik (52,3\%), namun mayoritas memiliki sikap positif terhadap pencegahan Covid-19 (86,4\%).
Tabel 2 memperlihatkan bahwa seluruh responden telah mengetahui siapa yang memiliki risiko tingkat keparahan tertinggi (100\%), penegakan diagnosis Covid-19 $(100 \%)$, serta cara menjaga kesehatan dan daya tahan tubuh yang baik (100\%). Namun sebagian besar responden tidak mengetahui lama waktu yang tepat untuk berjemur di bawah sinar matahari $(70,5 \%)$, mencuci tangan dengan sabun dan air mengalir (75\%), dan mencuci tangan dengan hand sanitizer secara benar $(68,2 \%)$.

Tabel 1. Karateristik sosiodemografi anggota komunitas musik Indonesian Bloodbrothers

\begin{tabular}{lcc}
\hline \multicolumn{1}{c}{ Variabel } & N & \% \\
\hline Jenis kelamin & & \\
Laki-laki & 25 & 56,8 \\
Perempuan & 19 & 43,2 \\
Usia (tahun) & & \\
$\quad<30$ & 15 & 34,1 \\
$>30$ & 29 & 65,9 \\
Wilayah tinggal & & \\
Jakarta & 24 & 54,6 \\
Bogor, Depok, & 20 & 45,4 \\
Tangerang, Bekasi & & \\
Pendidikan & & \\
D3/S1/S2 & 10 & 22,7 \\
SMU & 34 & 77,3 \\
Pekerjaan & & \\
Bekerja & 29 & 65,9 \\
Tidak Bekerja & 15 & 34,1 \\
Pendapatan perbulan & & \\
Tetap & 25 & 56,8 \\
Tidak Tetap & 19 & 43,2 \\
Pengetahuan & & \\
Baik & 21 & 47,7 \\
Kurang Baik & 23 & 52,3 \\
Sikap & & \\
Positif & 38 & 86,4 \\
Negatif & 6 & 13,6 \\
\hline & &
\end{tabular}

Tabel 3 memperlihatkan bahwa rerata tingkat pengetahuan responden berbeda secara bermakna berdasarkan usia $(p=0,001)$, wilayah tinggal $(\mathrm{p}=0,004)$ serta status pekerjaan $(\mathrm{p}=0,032)$. Tabel 4 memperlihatkan gambaran sikap responden yang secara umum menyetujui langkah-langkah terbaik dalam melakukan pencegahan penularan. 
Tabel 2. Pengetahuan komunitas musik tentang pencegahan Covid-19.

\begin{tabular}{lcc}
\hline Pengetahuan & Benar (\%) & Salah (\%) \\
\hline 1. Nama virus penyebab Covid-19 & $30(68,2)$ & $14(31,8)$ \\
2. Metode penularan Covid-19 & $11(25)$ & $33(75)$ \\
3. Anggota tubuh yang menjadi jalur transmisi Covid-19 & $41(93,2)$ & $3(6,8)$ \\
4. Gejala umum Covid-19 & $40(90,9)$ & $4(9,1)$ \\
5. Risiko penularan Covid-19 & $44(100)$ & 0 \\
6. Individu dengan risiko tingkat keparahan penyakit & $44(100)$ & 0 \\
7. Penegakkan diagnosa Covid-19 & $44(100)$ & 0 \\
8. Cara menjaga daya tahan tubuh & $44(100)$ & 0 \\
9. Lama waktu berjemur dibawah sinar matahari & $13(29,5)$ & $31(70,5)$ \\
10. Tindakan pencegahan Covid-19 yang tepat & $30(68,2)$ & $14(31,8)$ \\
11. Makna dari physical distancing & $38(86,4)$ & $6(13,6)$ \\
12. Lama waktu mencuci tangan dengan sabun dan air mengalir & $11(25)$ & $33(75)$ \\
13. Lama waktu mencuci tangan dengan hand sanitizer & $14(31,8)$ & $30(68,2)$ \\
14. Cara membersihkan permukaan benda yang diduga terpapar virus & $43(97,7)$ & $1(2,3)$ \\
15. Benda-benda yang rawan menjadi sarana penularan Covid-19 & $44(100)$ & 0 \\
16. Terapi pengobatan untuk Covid-19 & $36(81,8)$ & $8(18,2)$ \\
17. Hal yang sebaiknya dilakukan oleh seseorang yang terdiagnosa & $39(88,6)$ & $5(11,4)$ \\
positif Covid-19 dengan gejala ringan & $38(86,4)$ & $6(13,6)$ \\
18. Hal yang sebaiknya dilakukan setelah beraktivitas diluar rumah & $26(59,1)$ & $18(40,9)$ \\
19. Hal yang sebaiknya dilakukan setelah pulang berpergian dari daerah & & $2(4,5)$ \\
yang termasuk zona merah & $42(95,5)$ & \\
20. Cara mencuci tangan yang baik dan benar & &
\end{tabular}

Tabel 3. Perbedaan nilai rerata pengetahuan komunitas musik berdasarkan karateristik sosiodemografi

\begin{tabular}{lcc}
\hline \multicolumn{1}{c}{ Karateristik Sosiodemografi } & Mean $($ SD) & Nilai p \\
\hline Jenis kelamin & & \\
$\quad$ Laki-laki & $75,80( \pm 8,12)$ & 0,626 \\
$\quad$ Perempuan & $74,74( \pm 8,41)$ & \\
Usia & & \\
$\quad<30$ tahun & $81,00( \pm 6,87)$ & $0,001^{*}$ \\
$\quad>30$ tahun & $72,41( \pm 7,27)$ & \\
Wilayah Tinggal & & \\
$\quad$ Jakarta & $78,54( \pm 8,01)$ & $0,004^{*}$ \\
$\quad$ Bodetabek & $71,50( \pm 6,71)$ & \\
Tingkat Pendidikan & & \\
$\quad$ D3/S1/S2 & $76,18( \pm 7,98)$ & 0,150 \\
$\quad$ SMU & $72,50( \pm 8,58)$ & \\
Status Pekerjaan & & \\
$\quad$ Bekerja & $73,45( \pm 7,57)$ & $0,032^{*}$ \\
$\quad$ Tidak bekerja & $79,00( \pm 8,28)$ & \\
Status Pendapatan & & \\
$\quad$ Tetap & $74,60( \pm 6,60)$ & 0,584 \\
$\quad$ Tidak tetap & $76,32( \pm 9,98)$ & \\
\hline
\end{tabular}

*uji Mann-Whitney, $\mathrm{p}<0,05$ 
Tabel 4. Sikap anggota komunitas musik tentang pencegahan Covid-19

\begin{tabular}{|c|c|c|c|}
\hline Sikap & $\begin{array}{l}\text { Setuju } \\
\text { n }(\%)\end{array}$ & $\begin{array}{l}\text { Ragu- } \\
\text { ragu } \\
\text { n }(\%)\end{array}$ & $\begin{array}{l}\text { Tidak } \\
\text { setuju } \\
\text { n }(\%)\end{array}$ \\
\hline $\begin{array}{l}\text { 1. Saya menganggap pandemi Covid-19 ini sebagai masalah yang } \\
\text { serius }\end{array}$ & $44(100)$ & 0 & 0 \\
\hline $\begin{array}{l}\text { 2. Saya harus menjaga diri saya dan keluarga saya dengan baik dari } \\
\text { bahaya penularan Covid-19 }\end{array}$ & $44(100)$ & 0 & 0 \\
\hline $\begin{array}{l}\text { 3. Saya memakai masker medis setiap kali akan beraktivitas di luar } \\
\text { rumah }\end{array}$ & $41(93,2)$ & $3(6,8)$ & 0 \\
\hline $\begin{array}{l}\text { 4. Saya mencuci tangan dengan sabun dan air mengalir sebelum } \\
\text { makan atau menyentuh wajah }\end{array}$ & $38(86,4)$ & $6(13,6)$ & 0 \\
\hline $\begin{array}{l}\text { 5. Saya mempelajari bagaimana metode cuci tangan yang benar dan } \\
\text { melakukannya }\end{array}$ & $42(95,5)$ & $2(4,5)$ & 0 \\
\hline $\begin{array}{l}\text { 6. Saya mengurangi atau meniadakan aktivitas yang membutuhkan } \\
\text { tatap muka secara langsung }\end{array}$ & $35(79,5)$ & $9(20,5)$ & 0 \\
\hline $\begin{array}{l}\text { 7. Saya menunda untuk berpergian keluar kota atau wilayah diluar } \\
\text { tempat tinggal saya }\end{array}$ & $38(86,4)$ & $6(13,6)$ & 0 \\
\hline $\begin{array}{l}\text { 8. Saya mencari informasi tentang Covid-19 melalui artikel atau } \\
\text { sumber resmi yang terpercaya }\end{array}$ & $36(81,8)$ & $8(18,2)$ & 0 \\
\hline $\begin{array}{l}\text { 9. Menurut saya pemerintah telah melakukan langkah-langkah terbaik } \\
\text { dalam melakukan pencegahan penularan Covid-19 di masyarakat }\end{array}$ & $17(38,6)$ & $19(43,2)$ & $8(18,2)$ \\
\hline $\begin{array}{l}\text { 10. Menurut saya pembatasan sosial berskala besar sangat tepat untuk } \\
\text { mencegah penularan Covid-19 di masyarakat }\end{array}$ & $26(59)$ & $9(20,5)$ & $9(20,5)$ \\
\hline
\end{tabular}

\section{BAHASAN}

Pada penelitian ini terlihat bahwa responden secara umum masih memiliki pengetahuan yang kurang baik mengenai Covid-19 (52,3\%). Hasil ini berbeda jauh dengan penelitian lain di Indonesia yang menemukan tingkat pengetahuan baik pada lebih dari $80 \%$ responden. ${ }^{15,16} \mathrm{Hal}$ ini dapat disebabkan karena perbedaan karateristik demografi responden, yaitu mayoritas responden penelitian ini memiliki tingkat pendidikan SMU atau setara $(77,3 \%)$ dan pekerjaan di sektor informal.

Terdapat $68,2 \%$ dari responden dapat menjawab dengan tepat bahwa etiologi Covid-19 ialah Sars-CoV-2. Hasil ini tidak sejalan dengan penelitian sebelumnya di Indonesia yang mendapatkan sebanyak 95,5\% responden mengetahui secara tepat etiologi Covid-19. ${ }^{16}$ Hal ini dapat disebabkan karena responden mengetahui bahwa etiologi Covid-19 ialah virus, namun tidak dapat menjelaskan secara spesifik nama virus yang dimaksud.

Seluruh responden mengetahui bahwa Covid-19 dapat menginfeksi seluruh kelompok usia (100\%), dengan risiko tingkat keparahan tertinggi pada kelompok lanjut usia dan penyakit komorbid (100\%). Berbagai penelitian mengenai Covid-19 mendapatkan bahwa kasus positif yang ditemukan memiliki berbagai variasi usia, dari mulai antara 2-72 tahun. ${ }^{17}$ Data pemantauan Covid-19 DKI Jakarta telah melaporkan kasus positif dari mulai usia di bawah 1 tahun sampai dengan di atas 59 tahun. ${ }^{18}$ Prevalensi kematian pada anak usia di bawah 5 tahun yang dirawat di rumah sakit karena Covid-19 di Jakarta ditemukan mencapai $11 \% .^{2}$ Hal ini menunjukkan bahwa kewaspadaan terhadap penyakit ini harus ditingkatkan pada seluruh kelompok usia.

Mayoritas responden mengetahui bahwa metode mencuci tangan yang tepat ialah dengan membersihkan seluruh bagian tangan termasuk punggung, telapak, ujung kuku dan sela-sela jari $(95,5 \%)$. Namun sebagian besar responden tidak mengetahui lama waktu yang tepat untuk melakukan cuci tangan baik dengan air mengalir dan sabun $(75 \%)$ maupun dengan hand sanitizer $(78,2 \%)$. Cara mencuci tangan yang baik dan benar sesuai dengan panduan WHO ialah dengan menggunakan sabun cair dan 
air mengalir selama 40 sampai 60 detik. Gerakan membersihkan dengan cara menggosok dilakukan pada kedua telapak tangan, punggung tangan, sela-sela jari, dan kuku secara bergantian. Jika tidak tersedia sabun cair dan air mengalir yang bersih, maka langkah-langkah tersebut dapat dilakukan dengan menggunakan hand sanitizer gel berbahan dasar alkohol $70 \%$ dengan durasi 20-30 detik. ${ }^{19}$

Sebanyak $59,1 \%$ responden dalam penelitian ini mengetahui bahwa mereka harus melakukan isolasi mandiri selama 14 hari setelah melakukan perjalanan dari daerah yang termasuk zona merah. Sebuah peneliian melaporkan bahwa risiko penularan Covid 19 dalam keluarga meningkat 18 kali lebih tinggi seiring kontak erat dengan anggota keluarga yang terinfeksi $(\mathrm{OR}=18,26$; $95 \% \mathrm{CI}=3,93-84,79)$. Definisi kontak erat adalah beraktivitas bersama dengan jarak di bawah 1 meter dalam waktu lebih dari 10 menit. ${ }^{20}$ Kontak erat juga dapat terjadi ketika anggota keluarga berbagi makanan, ruangan, atau kendaraan dengan individu yang terinfeksi dalam waktu 14 hari. ${ }^{21}$ Seorang individu yang tidak mengisolasi dirinya dengan baik setelah berpergian dari zona merah, memiliki risiko menulari anggota keluarganya yang berada dalam satu rumah apabila ternyata ia terinfeksi Covid-19.

Pada penelitian ini didapatkan perbedaan nilai pengetahuan yang bermakna secara statistik berdasarkan variabel usia $(p=0,001)$, wilayah tinggal $(\mathrm{p}=0,004)$, dan status pekerjaan $(\mathrm{p}=0,032)$. Responden yang berusia $<30$ tahun memiliki nilai rerata pengetahuan yang lebih tinggi $(81,0 \pm 6,87)$ dibandingkan responden yang berusia $>30$ tahun $(72,41 \pm$ 7,27). Hal ini dapat disebabkan karena kelompok usia yang lebih muda memiliki akses informasi yang lebih luas dari berbagai sumber, dan mampu menyaring informasi dengan baik. ${ }^{16}$

Responden yang berdomisili di wilayah Jakarta memiliki nilai rerata pengetahuan yang lebih tinggi $(78,54 \pm 8,01)$ dibandingkan dengan responden yang berdomisili di luar Jakarta seperti Bogor, Depok, Tange-

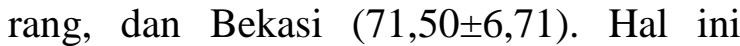
selaras dengan beberapa penelitian lain di
Asia yang menunjukkan bahwa masyarakat yang berdomisili di wilayah perkotaan atau mendekati pusat pemerintahan, memiliki tingkat pengetahuan yang lebih baik mengenai pencegahan penularan Covid-19.7,22 Responden yang berkerja memiliki nilai rerata pengetahuan yang lebih rendah $(73,45$ $\pm 7,57)$ dibandingkan dengan responden yang tidak bekerja $(79,00 \pm 8,28)$. Hal ini dapat disebabkan karena responden yang bekerja umumnya memiliki pekerjaan di sektor informal dengan pendapatan tidak tetap per bulan, sementara responden yang belum bekerja umumnya sedang menempuh jenjang pendidikan formal sehingga memiliki akses informasi yang lebih baik.

Mayoritas responden memiliki sikap yang positif terhadap pencegahan penularan Covid-19 (86,4\%). Seluruh responden setuju bahwa pandemi Covid-19 ini merupakan masalah serius dan mereka harus berupaya untuk melindungi diri serta keluarga dengan baik. Hal ini sejalan dengan penelitian di negara lain, dimana umumnya masyarakat menganggap pandemi ini sebagai ancaman bagi kehidupan dan mereka sangat mengkhawatirkan terjadinya risiko infeksi pada anggota keluarga. ${ }^{23}$ Perlu menjadi perhatian bahwa hanya $38,6 \%$ responden yang menyetujui bahwa pemerintah telah melakukan langkah-langkah terbaik dalam pencegahan penularan Covid-19 di masyarakat.

Limitasi penelitian ini ialah keterbatasan jumlah responden dan karateristik responden yang hanya berasal dari sebuah komunitas informal sehingga hasil penelitian tidak dapat mewakili keseluruhan populasi pada wilayah yang sama. Selain itu, penelitian ini dilakukan secara daring sehingga hanya berhasil menjangkau responden yang memiliki sarana dan prasarana memadai seperti akses jaringan internet. Kuesioner yang digunakan masih memerlukan uji validitas dan reliabilitas lebih lanjut untuk dapat diterapkan pada populasi lain.

\section{SIMPULAN}

Pengetahuan anggota komunitas musik Indonesian Bloodbrothers di wilayah DKI Jakarta dan sekitarnya (JABODETABEK) tentang pencegahan Covid-19 masih kurang 
baik walaupun mayoritas memiliki sikap yang positif. Peningkatan pengetahuan melalui kegiatan penyuluhan masih perlu dilakukan supaya dapat menjadi bekal untuk aktif berpartisipasi dalam mencegah penularan Covid-19 di masyarakat.

\section{Konflik Kepentingan}

Penulis menyatakan tidak terdapat konflik kepentingan dalam studi ini

\section{Ucapan Terima Kasih}

Ucapan terima kasih ditujukan kepada Fakultas Kedokteran Gigi Universitas Trisakti yang telah membantu pelaksanaan kegiatan penelitian ini.

\section{DAFTAR PUSTAKA}

1. Susilo A, Rumende CM, Pitoyo CW, Santoso WD, Yulianti M, Herikurniawan, et al. Coronavirus disease 2019: Tinjauan literatur terkini. Jurnal Penyakit Dalam Indonesia. 2020;7(1):145-67.

2. Surendra H, Elyazar IR, Djaafara BA, Ekawati LL, Saraswati K, Adrian V, et al. Clinical characteristics and mortality associated with COVID-19 in Jakarta, Indonesia: a hospital-based retrospective cohort study. The Lancet Regional Health-Western Pacific. 2021;9:100108.

3. Siddiqui AA, Alshammary F, Amin J, Rathore HA, Hassan I, Ilyas M, Alam MK. Knowledge and practice regarding prevention of COVID-19 among the Saudi Arabian population. Work. 2020; 66(4):767-75.

4. Khan AM, Nawabi S, Javed MQ. Dental Faculty's knowledge and attitude regarding COVID-19 disease in Qassim, Saudi Arabia. Infect Dis. 2020, 10.21203/rs.3.rs-25306/v1.

5. Windarwati HD, Oktaviana W, Mukarromah I, Ati NAL, Rizzal AF, Sulaksono AD. In the middle of the COVID-19 outbreak: early practical guidelines for psychosocial aspects of COVID-19 in East Java, Indonesia. Psychiatry Res. 2020; 293:113395.

6. Kementerian Kesehatan RI. Pedoman pencegahan dan pengendalian coronavirus disease (COVID-19). 2020; p. 17-24.

7. Azlan AA, Hamzah MR, Sern TJ, Ayub SH, Mohamad E. Public knowledge, attitudes and practices towards COVID-19: a cross-sectional study in Malaysia. PLoS One. 2020;15(5):e0233668.

8. Zhong BL, Luo W, Li HM, Zhang QQ, Liu XG, Li WT, Li Y. Knowledge, attitudes, and practices towards COVID-19 among Chinese residents during the rapid rise period of the COVID-19 outbreak: a quick online cross-sectional survey. Int J Biol Sci. 2020;16(10):1745-52.

9. Akalu Y, Ayelign B, Molla MD. Knowledge, attitude and practice towards COVID19 among chronic disease patients at Addis Zemen Hospital, Northwest Ethiopia. Infect Drug Resist. 2020;13: 1949-60.

10. Riiser K, Helseth S, Haraldstad K, Torbjørnsen A, Richardsen KR. Adolescents' health literacy, health protective measures, and health-related quality of life during the Covid-19 pandemic. PLoS One. 2020; 15(8):e0238161.

11. Arikunto S. Dasar-dasar Evaluasi Pendidikan (2nd ed). Jakarta: PT. Bumi Aksara; 2013.

12. Notoatmodjo S. Promosi Kesehatan dan Ilmu Perilaku. Jakarta: PT. Rineka Cipta; 2014.

13. Van Nhu H, Tuyet-Hanh TT, Van NTA, Linh TNQ, Tien TQ. Knowledge, attitudes, and practices of the Vietnamese as key factors in controlling COVID-19. J Community Health. 2020;45(6):1263-9.

14. Dkhar SA, Quansar R, Saleem SM, Khan SMS. Knowledge, attitude, and practices related to COVID-19 pandemic among social media users in J\&K, India. Indian J Public Health. 2020; 64:S205S210.

15. Halim AD, Kurniawan A, Agung FH, Angelina S, Jodhinata C, Winata S, et al. Understanding of young people about COVID-19 during early outbreak in Indonesia. Asia Pac J Public Health. 2020;32(6-7):363-5.

16. Sari DK, Amelia R, Dharmajaya R, Sari LM, Fitri NK. Positive correlation between general public knowledge and attitudes regarding COVID-19 outbreak 1 month after first cases reported in Indonesia. J Community Health. 2021;46(1):182-9.

17. Adhikari SP, Meng S, Wu YJ, Mao YP, Ye RX, Wang QZ, et al. Epidemiology, causes, clinical manifestation and diagnosis, prevention and control of coronavirus disease (COVID-19) during the 
early outbreak period: a scoping review. Infect Dis Poverty. 2020;9(1):29.

18. Data Pemantauan COVID-19 DKI Jakarta. Available from: https://corona.jakarta. go.id/id/data-pemantauan

19. Hillier MD. Using effective hand hygiene practice to prevent and control infection. Nurs Stand. 2020;35(5):45-50

20. Wang Y, Tian H, Zhang L, Zhang M, Guo D, $\mathrm{Wu} \mathrm{W}$, et al. Reduction of secondary transmission of SARS-CoV-2 in households by face mask use, disinfection and social distancing: a cohort study in Beijing, China. BMJ Glob Health. 2020;5(5):e002794.

21. Li J, Ding J, Chen L, Hong L, Yu X, Ye E, et al. Epidemiological and clinical characteristics of three family clusters of
COVID-19 transmitted by latent patients in China. Epidemiol Infect. 2020;148:e137.

22. Banik, R., Rahman, M., Sikder T, Rahman QM, Pranta MUR. Knowledge, attitudes, and practices related to the COVID-19 pandemic among Bangladeshi youth: a web-based crosssectional analysis. J Public Health (Berl.) (2021). Availabe from: https: //doi.org/10.1007/s10389-020-01432-7

23. Abdelhafiz AS, Mohammed Z, Ibrahim ME, Ziady HH, Alorabi M, Ayyad M, et al. Knowledge, perceptions, and attitude of Egyptians towards the novel coronavirus disease (COVID-19). J Community Health. 2020;45(5):881-890. 